\title{
The downfall of Mikhail Gorbachev
}

Pity poor Russia, the other quondam republics of the Soviet Union, the most talented and the most deprived part of the scientific community and also Mikhail Gorbachev (who may yet recover, but not quickly).

THE hard men of Moscow are not the only ones to blame for the unconstitutional sacking last week of Mr Mikhail Gorbachev from his post as President of the Soviet Union; he must also shoulder some of the blame. But only relatively little of it. Gorbachev has been a courageous and daring politician in the past five years. $\mathrm{He}$ has made glasnost and perestroika components of an international vocabulary. He has also edged the Soviet Union substantially towards constitutional reform - it is not an accident that his deposition came on the eve of approval of the new union treaty by at least five republics of the union - and has even committed his government to economic reform of a lasting kind. Even more important, he has demonstrated that the Soviet Union can abandon its prejudices against the outside world to the extent of signing treaties for the control of strategic arms, while Gorbachev's influence has given the satellite states of Eastern Europe a freedom they could not previously have expected.

These achievements have been marred in only three important ways - Gorbachev never had the courage to resign his post as general secretary of the Soviet Communist Party, he never took the risk of plumping for one of the economic programmes that might have worked and he allowed the Soviet army brutally to repress dissent in the Baltic states earlier this year. For the time being, it remains a mystery that a man of so much courage should have allowed compromises to dominate his short political life so far. Whether last week's events mark the end of his career is another matter. On the face of things, what is left of the Soviet Union cannot indefinitely manage without him.

Civil war, which has been on the cards for the past two years, is now the most likely outcome; too many of the republics - notably the Baltic states and Georgia have gone too far down the road to independence easily to give up. Similarly, Mr Boris Yeltsin has done too much to assert the autonomy of the Russian republic for him easily to eat his words.

Meanwhile, we should all grieve for the condition of the Soviet people. That the economy has virtually collapsed is apparent from the empty shops, but this is only the most visible symptom of decline. It is even more significant that industrial production has fallen by more than 15 per cent in the past two years. Public services, once the Soviet Union's great pride, are meanwhile in decline caused by under-investment and bureaucratic neglect. The research establishment - huge by any other standards, but under-productive for the past several decades - faces a still more miserable future. None of that will be made better if people choose to begin killing each other for the sake of a little freedom. Does the new Kremlin appreciate that truth?

\section{Electoral sustainability}

The British Liberal Democrats are risking too much in their plans to create a green economy

To campaign successfully for election to public office by promising to increase taxes is usually an uphill struggle as Mr Walter Mondale found when, in 1984, he fought then Mr Ronald Reagan for the US presidency - and lost. The British political party called the Liberal Democrats, with which appear to rest the electoral hopes of some 15 per cent of the British population, seems entirely undeterred by Mondale's experience.

Last week, the party published a document called Costing the Earth which offers British people better environmental protection and what is called sustainable development in exchange for taxes on energy consumption and other devices. The advocacy of a grandiose unilateral policy of self-restraint on energy consumption and environmental damage is mistaken for at least two reasons (political expediency apart). First, the doctrine of fiscal neutrality is seductively over-simple. It is all very well to say that energy taxes would be offset by tax reductions elsewhere in the national budget, but would these fall in just the way that would preserve the competitiveness (such as it is) of British manufacturing? 742 The second obvious objection is linked with the first. Surprisingly for a party with a proper claim to international awareness the Liberal Democrats now pretend that Britain, acting alone on energy taxes and the like, can make a decisive contribution to global "sustainability" by acting unilaterally.

But that is a nonsense. It might be possible, by manipulating taxes in Britain, to drive energy-intensive industries elsewhere, but the Liberal Democrats would have been made a stronger claim on public attention if they had advocated international negotiations for the general adoption of their unilateral programme. 